\title{
PELAKSANAAN KREDIT PADA PT. BPR LENGAYANG
}

\author{
Vina Resmadita, Ratna Widayati \\ Akademi Keuangan dan Perbankan "Pembangunan" AKBP Padang \\ vinaresmaditavina@gmail.com
}

\begin{abstract}
The purpose of this study was to determine the implementation of lending at PT.BPR Lengayang. To analyze the research data, the author uses qualitative data analysis methods as a research method that describes descriptively the implementation of lending at PT. BPR Lengayang. Credit is the capacity to make a purchase or carry out a loan with the promise of payment to be made or deferred within an agreed period of time. In the implementation of lending to PT. $B P R$ Lengayang has several stages, namely the credit application stage, credit analysis, credit approval stage, signing credit / agreement, disbursement stage, customer business supervision, credit repayment.
\end{abstract}

Keywords: Credit, Implementation of credit

\section{PENDAHULAN}

Dunia perbankan sebagai pelaku ekonomi merupakan salah satu institusi keuangan yang turut serta dan ikut berpartisipasi dalam pemerataan pembangunan.Oleh karenaitu, bank harus bertindak efektif dan efisien. Efektif berarti bahwa bank harus menyimpan dana,mampu memberi kredit dan memberikan jasa pelayanan lainnya,sedangkan arti efisien adalah bagaimana kerja bank tersebut bagus dalam aktivitas operasionalnya untuk memperoleh tujuan di dalam perbankan.

MenurutUndang-undang RI Nomor 10 Tahun 1998 tentang Perbankan pasal 1 (2) yang dimaksud dengan bank adalah badan usaha yang menghimpun dana dari masyarakat dalam bentuk simpanan dan menyalurkannya kepada masyarakat dalam bentuk kredit dan atau bentukbentuk lainnya dalam rangka meningkatkan taraf hidup rakyat banyak.

Dari pengertian diatas dapat dijelaskan secara lebih luas lagi bahwa bank merupakan perusahaan yang bergerak dalam bidang keuangan, artinya kegiatan perbankan selalu berkaitan dalam bidang keuangan sehingga berbicara mengenai bank tidak terlepas dari masalah keuangan (Kasmir, 2013). Sedangkan menurut(Wilardjo, 2014) bank adalah lembaga perantara keuangan atau biasa disebut Financial intermediary. Artinya, lembaga bank adalah lembaga yang dalam aktivitasnya berkaitan dengan masalah uang. Oleh karena itu, usaha bank akan selalu dikaitkan dengan masalah uang yang merupakan alat alat pelancar terjadinya perdagangan yang utama.

Dalam menjalankan fungsinya tersebut,bank memberikan beragam kredit kepada nasabah. Kemudian bank akan memperoleh keuntungan yang amatbesar yang terimapada usaha penyalurannya(kredit), begitupun sebaliknya bank juga dapat memperoleh risiko kerugian yang amat besar jika 
penyaluran(kredit) tidak berjalan dengan lancar.Maka dari itu pemberian kredit terhadap nasabah harus diberikan dengan cermat oleh karyawan yang paham dengan dasar-dasar perkreditan serta dengan kebijakan aturan perkreditan agar bebas dari resiko kredit bermasalah.

Dalam melakukan penelitian ini penulis meneliti tentang pelaksanaan kredit dengan alasanuntuk mengetahui proses pemberian kredit dimulai dari permohonan kredit hingga proses pencairan kredit, yang mana dapat dilihat dari perkembangan pemberian kredit dan perkembangan penerimaan kredit.

Menurut (Kasmir, 2013) BPR adalah bank yang melakukan aktivitas usaha sebagai konvensional berdasarkanprinsip syariah yang berarti aktivitasnya tidak memberikan pelayananpada lalu lintas pembayaran. Artinya BPR jauh lebih sempit jika dibandingkan dengan aktivitas bank umum.

Bank Perkreditan Rakyat salah satu bentuk bank yang membantu pengusaha mikro, Kecil, dan menengah dengan lokasi yang pada umumnya dekat dengan tempat masyarakat yang memerlukan. (Gustiyan, 2014). Sedang kan menurut (Shanjaya \& Marlius, 2018)BPR adalah lembaga keuangn bank yang menerima simpanan hanya dalam bentuk deposito berjangka, tabungan, dan atau bentuk lainnya yang dipersamakan dan menyalurkan dana sebagai usaha BPR.

\section{METODE PENELITIAN}

Metode yang digunakan: Studi Kepustakaan (Library Research)

Penelitian ini dilakukan dengan cara mempelajari dan membaca referensi penelitian yang diperoleh di perpustakaan dan artikel-artikel yang bersangkutan dengan penelitian.

Studi Lapangan (Field Research)

Penelitian langsung pada objek yang bersangkutan dengan meneliti hasil data yang diperoleh.Penelitian ini bisa mendukung penulis dalam melengkapi data yang diperlukan,dengan kegiatan yang dilakukan mewawancarai pihak-pihak yang berkepentingan atau pihak perusahaan,instansi yang terkait.

\section{HASIL DAN PEMBAHASAN \\ Pengertian Bank}

Menurut Undang-Undang RI Nomor 10 Tahun 1998 tentang perbankan pasal 1 (2) Bank merupakan badan usaha yang menghimpun dana dari masyarakat dalam bentuk simpanan dan menyalurkannya dalam bentuk kredit dan atau bentuk-bentuk lainnya dalam rangka memajukan taraf hidup rakyat banyak (Amelia \& Marlius, 2018).

Berdasarkan arti tersebut dapat disimpulkan fungsi bank ada dua yaitu penghimpun dana dari masyarakat dan menyalurkan kembali dananya ke masyarakat melalui kredit. 


\section{Pengertian Bank Perkreditan Rakyat}

Menurut Undang-Undang RI Nomor 10 tentang Bank Perkreditan Rakyat (BPR) pasal 1 (4) BPR merupakan bank yang melakukanaktivitas usaha sebagai konvensional atau berdasarkanprinsip syariah yang aktivitasnya tidak membagikan jasa pada lalu lintas pembayaran.

Usaha BPR yang diperolehkan yaitu menghimpun dana dari masyarakat, memberikan kredit,menyediakan pembiayaan bagi nasabah berlandaskan dasar bagi hasil, meletakkan dananya dalam bentuk SBI, deposito, dan tabungan, sedangkan aktivitas usaha yang tidak diperkenankan BPR ialah menerima simpanan dalam bentuk giro, melakukan penyertaan modal, melakukan usaha perasuransian, melakukan usaha lain diluar kegiatan usaha diatas (Jadmiko, n.d.)

Dengan kedudukan yang biasanya dekat dengan tempat masyarakat yang memerlukan.Status BPR diberikan kepada bank desa, bank pasar, bank pegawai, lumbung pitihnagari (LPN), lembaga perkreditan desa(LPD), badan kredit desa(BKD), badan kredit kecamatan(BKK), dan lain-lainnya (Andriani \& Susanto, 2019)

Usaha yang Dapat Dilakukan Oleh Bank Perkreditan Rakyat Menurut Peraturan Bank Indonesia No.6 /22/PBI/2004

Berikut kegiatan yang dapat dilaksanakan oleh BPR antara lain:

1. Menghimpun dana dari masyarakat dalam bentuk simpanan berupa deposito berjangka, dan atau bentuk lainnya yang dipersamakan dengan itu.

2. Memberikan kredit.

3. Menyediakan pembiayaan dan menempatkan dana berdasarkan prinsip syariah, sesuai dengan ketentuan yang ditetapkan oleh bank indonesia.

4. Menempatkan dananya dalam bentuk sertifikat bank indonesia (SBI), deposito berjangka, sertifikat deposito dan atau tabungan pada bank lain.

Usaha Yang Tidak Dapat Dilakukan Oleh bank Perkreditan Rakyat Menurut Bank Indonesia No. 6/22/PBI/2004

Usaha yang tidak boleh dilakukan oleh BPR sebagai berikut:

1. Menerima simpanan berupa giro.

2. Melakukan kegiatan usaha dalam valuta asing.

3. Melakukan penyertaan modal dengan prinsip prudent banking dan concern terhadap layanan kebutuhan masyarakat menengah kebawah.

\section{Pengertian Kredit}

4. Melakukan usaha peransuransian.

Kredit berasal dari bahasa italia, Credere yang artinya kepercayaan, yaitu kepercayaan dari kreditur bahwa debiturnya akan mengembalikan pinjaman beserta bunganya sesuai dengan perjanjian kedua belah pihak. Penyediaan uang atau tagihan yang bisa dipersamakan dengan itu berlandaskan kesepakatan pinjam-meminjam antara bank dengan pihak lain yang mewajibkan pihak peminjam untuk melunasi hutangnya setelah jangka waktu tertentu dengan jumlah bunga imbalan atau pembagian hasil keuntungan. Semua jenis pinjaman yang harus dibayar kembali bersama 
bunganya oleh peminjam sesuai dengan perjanjian yang telah disepakati (Widayati \& Efriani, 2019).

Kredit adalah kapasitas akan melakukan suatu pembelian atau melaksanakan suatu peminjaman dengan janji pembayaran akan dilakukan atau ditangguhkan pada jangka waktu yang telah disepakati.(Anggraini \& Nasution, 2013)

\section{Jenis-Jenis Kredit}

Menurut (Alanshari \& Marlius, 2018) Secara umum jenis-jenis kredit yang ditawarkan oleh bank adalah:
a. Kredit investasi
Yaitu kredit yang diberikan terhadap pengusaha penanaman modal.
b. Kredit modal kerja
Merupakan kredit yang diberikanuntuk modal kerja dan berjangka pendek tidak lebih dari 1 (satu) tahun.
c. Kredit perdagangan
Merupakan kredit yang diberikan pada para pedagang dalam rangka memperlancaraktivitas perdagangannya.
d. Kredit produktif
Merupakan kredit yang diberikan untuk diusahakan kembali sehingga pengambilan kredit diharapkan dari hasil usaha yang dibiayai,
e. Kredit profesi
Merupakan kredit yang diberikan kepada para kalangan profesional seperti dosen, dokter, atau pengacara.

\section{Prinsip-prinsip Pemberian kredit}

Hal-hal yang harus diperhatikan oleh kreditur untuk melihat debitur yang layak menerima kredit yaitu harus memenuhi prinsip $5 \mathrm{c}, 7 \mathrm{p}$, dan $3 \mathrm{R}$ sebagai berikut:

Penilaian berdasarkan prinsip 5c sebagai berikut:

a. Character (karakteristik)

Adalah ini melibatkan dengan sisi psikologis calon penerima kredit itu sendiri,yaitu karakter maupun sifat yang dimilikinya,seperti latar belakang keluarganya,hobi,cara hidup yang dijalani dan kebiasaankebiasaannya.

b. Capacity (kemampuan)

Adalah melibatkan dengan "business record" atau kemampuan seseorang pebisnis mengelola usahanya,terutama pada masa-masa sulit sehingga besok akan tampak "ability to pay" atau kemampuan membayar.

c. Capital (modal)

Ini melibatkan dengan kemampuan dana yang dimiliki oleh seseorang pada saat ia melakukan usahanya tersebut.

d. Collateral (jaminan)

Merupakanbarang ataupun sesuatu yang dapat dijadikan agunan pada saat seseorang hendakmelaksanakan peminjaman danadalam bentuk angsuran ke sebuah perbankan atau leasing. 
e. Condition of economy (kondisi perekonomian)

Kondisi perekonomian yang tengah berlangsung di suatu daerah seperti tingkat perkembangan ekonomi yang tengah terjadi.

Penilaian berdasarkan prinsip $7 \mathrm{p}$ sebagai berikut:

a. Personality

Adalah penilaian pelanggan dari segi berkarakter ataupun tingkah lakunya sehari-hari maupun masa lalunya, mencakup sikap emosi tingkah laku dan aktivitas nasabah dalam menghadapi masaalah.

b. Party

Yaitu mengkategorikan nasabah kedalam kategori tertentu berdasarkan kepada modal,loyalitas dan karakternya.

c. Purpose

Yaitu untuk memahami tujuan nasabah dalam mengambil kredit,seperti tujuan konsumtif,produktif atau perdagangan.

d. Prospect

Adalah buat membandingkan usaha nasabah dimasa yang akan datang, apakah menguntungkan atau tidak.

e. Payment

Adalahukuran dengancaraapanasabah mengembalikan kredit yang sudah diambil atau dari sumber mana saja.

f. Profitability

Adalah untuk menganalisis bagaimana kemampuan nasabah dalam mencari laba,diukur dari periode ke periode apakah bakal tetap sama maupun semakin meningkat.

g. Protection

Yaitu bagaimana melindungi kredit yang dikucurkan oleh bank, namun melewati suatu perlindungan berbentuk agunan bahan mapun orang maupun agunan asuransi

Penilaian berdasarkan prinsip 3R sebagai berikut:

a. Return (hasil yang dicapai)

Adalahpenghargaanatas hasil yang hendakdicapaioleh perusahaan debitur sehabis dibantu dengan kredit oleh bank.

b. Repayment(pembayaran kembali)

Yaitu bank perlumemandingkan berapa lama industri pemohon kredit dapat melunasi kembali pinjamannya sesuai dengan kemampuan.

c. Risk bearing ability(kemampuan untuk menanggung resiko)

Yaitu bank mesti memahami dan membandingkan sampai sejauh mana perusahaan permohonan kredit mampu menanggung resiko.

\section{Aspek-Aspek Kelayakan Kredit}

Aspek- aspek kredit menurut(Tumbel2, 2015)sebagai berikut:

1. Aspek hukum/yuridis

Adalah masalah legalitis badan usaha dan izin-izin yang dimiliki oleh suatu perusahaan yang mengajukan kredit. Penilian dimulai dari meneliti keabsahan dan kesempurnaan akte pendirian perusahaan, sehingga dapat diketahui siapa-siapa pemiliknya dan besarnya modal masing-masing pemilik. 
2. Aspek pasar dan Pemaaran

Merupakan besar kecilnya permintaan terhadap produk yang dihasilkan ssekarang ini dan dimasa yang akan datang, sehingga diketahui prospek pemasaran produk tersebut yang perlu diteliti dalam aspek ini adalah:

a. Hasil penjualan atau produksi minimal tiga bulan yang lalu atau tiga tahun yang lalu.

b. Rencana penjualan dan produksi minimal tiga bulan atau tiga tahun yang akan datang.

c. Peta kekuatan pesaing yang ada seperti market share yang diketahui.

d. Prospek produk secara keseluruhan.

3. Aspek keuangan

Adalah sumber-sumber dana yang dimiliki untukm membiayai usahannya dan bagaimana penggunaan dana tersebut.

4. Aspek teknis/ operasi

Adalah aspek yang membahas masalah yang berkaitan dengan produksi, lokasi dan Lay out, seperti kapasitas mesin yang digunakan .

5. Aspek manajemen

Adalah digunakan untuk menilai struktur organisasi perusahaan, sumber daya manusia yang dimiliki serta latar belakang pendidikan dan pengalaman sumber daya manusia . pengalaman perusahaan dalam mengelola berbagau proyek yang ada juga menjadi pertimbangan lain.

6. Aspek Sosial/ ekonomi

Adalah menganalisis dampaknya yang ditumbulkan akibat adanya proyek

Komite kredit terhadap perekonomian masyarakat dan sosial masyarakat umum.

\section{Tugas Komite Kredit}

Menurut (Achmad Chosyali*, 2019) tugas komite kredit yaitu:

a. Memberikan persetujuan atau penolakan kredit atau pembiayaan sesuai dengan batas wewenang atau jenis kredit atau pembiayaan yang ditetapkan oleh direksi.

b. Melaksanakan tugas terutama dalam pemberian persetujuan kredit atau pembiayaan berdasarkan kompetensinya secara jujur, objektif, cermat, serta seksama.

c. Menolak permintaan dan pengaruh pihak yang berkepentingan dengan pemohon kredit maupun pembiayaan untuk memberikan persetujuan kredit maupun pembiayaan yang hanya bersifat formalitas.

\section{Fungsi Komite Kredit}

Menurut (Yuliana \& Widianti, 2014) komite kredit berfungsi sebagai mengkoordinir serta mengecek atas kredit yang disalurkan, melakukan analisis, serta menentukan keputusan pemberian fasilitas kredit.

\section{Proses Pemberian kredit}

Proses pemberian menurut (Widayati \& Putri, 2019) sebagai berikut:

a. Pengajuan berkas

Dituangkan dalam suatu proposal dengan melampirkan berkasberkas lainnya yang dibutuhkan, antara lain: 
1) Latar belakang perusahaan

a) Riwayat singkat perusahaan

b) Bidang Umum

c) Identitas perusahaan

d) Struktur organisasi perusahaan dan susunan pengurus

e) Perkembangan perusahaan serta realisasi dengan pihak-pihak pemerintah dan swasta.

2) Maksud dan tujuan

a) Memperbesar omset penjualan atau meningkatkan kapasitas produksi ataupun mendirikan pabrik baru (peluasan) serta tujuan lainnya.

b) Pemohon menentukan besarnya jumlah kredit yang ingin diperoleh dan jangka waktu kreditnya. Penilaian kelayakan besarnya kredit dan jangka waktu dapat dilihat dari cash flow serta laporan keuangan ( neraca dan laporan rugi laba) tahun terakhir. Jika dari hasil analisis tidak sesuai dengan permohonan, maka pihak bank tetap berpedoman terhadap hasil analisis mereka dalam memutuskan jumlah kredit dan jangka waktu kredit yang layak diberikan kepada permohon.

c) Cara pemohon mengembalikan kredit.

3) Jaminan kredit

Hal ini merupakan jaminan untuk menutupi segala risiko terhadap kemungkinan macetnya suatu kredit baik yang ada unsur kesengajaan atau tidak. Penilaian jaminan kredit haruslah teliti agar tidak terjadi sengketa, palsu, dan sebagainya. Pada jaminan ini dilampirkan:

a) Akte notaris

b) Tanda Daftar Perusahaan ( TDP)

c) Nomor Pokok Wajib Pajak ( NPWP)

d) Neraca dan Laba Rugi 3 ( tiga) tahun terakhir.

e) Bukti Diri diri Pengurus/ Pimpinan Perusahaan

f) Foto copy Sertifikat Jaminan.

b. Penyelidikan berkas Pinjaman

Tujuannya adalah untuk mengetahui apakah berkas yang diajukan sudah lengkap sesuai persyaratan dan sudah benar. Jika menurut pihak perbankan belum lengkap atau cukup, maka nasabah diminta untuk segara melengkapinya dan apabila sampai batas tertentu nasabah tidak sanggup melengkapi kekurangan tersebut, maka sebaiknya permohonan kredit dibatalkan saja. Untuk mengetahui kelengkapan berkas pinjaman tersebut maaka dilakukan hal-hal sebagai berikut:

1) Wawancara 1

Adalah penyidikan kepada calon peminjam secara langsung, untuk menegtahui segala informasi, keinginan dan kebutuhan nasabah yang sebenarnya, serta buat meyakinkan apakah berkas-berkas tersebut sesuai dan lengkap seperti yang diinginkan oleh bank. 
2) On The Spot

Adalah aktivitas pemeriksaan ke lapangan dengan meninjau berbagai objek yang dijadikan usaha maupun jaminan. Kemudian hasil on the spot dicocokkan dengan hasil wawancara 1. Pada saat hendak melakukan on the spot sebaiknya jangan memberitahu kepada nasabah, sehingga apa yang dilihat dilapangan sesuai dengan kondisi yang sebenarnya.

3) Wawancara 2

Adalah aktivitas pembetulan berkas, mungkin terdapat kekurangankekurangan pada saat setelah dilakukan on the spot di lapangan. Catatan yang ada pada permohonan dan pada saat wawancara 1 dicocokan dengan pada saat on the spot apakah ada kesesuaian dan mengandung suatu kebenaran.

c. Tahap keputusan kredit

Dokumen yang telah disetujui oleh kabid kredit diserahkan kepada direktur untuk diputuskan apakah disetujui tau ditolak. Jika disetujui maka disiapkan administrasi kredit tersebut yaitu:

1) Besar jumlah kredit yang disetujui

2) Jangka waktu kredit

3) Biaya-biaya yang harus dibayar oleh nasabah

4) Mempersiapkan pengikatan kredit atau perjanjian

d. Tahap pencairan

1) Apabila nasabah setuju dengan keputusan yang diambil bank maka pinjaman yang diajukan akan dicairkan.

2) Slip penarikan sebesar jumlah kredit yang telah disetujui diserahkan kepada kabag kredit untuk diotorisasi, selanjutnya diserahkan kepada sub bagian dana dan operasional dan pelaporan kas untuk diotorisasi direksi.

3) Berkas pencairan yang terdapat pada dokumen-dokumen diantaranya yaitu: jumlah yang diterima nasabah setelah dikurangi biaya- biaya seperti provisi, administrasi dan biaya premi asuransi dan anggaran pengikatan jaminan.

4) Setelah dokumen-dokumen tersebut di setujui dan telah ditanda tangani diserahkan kebagian pembukuan kemudian dibuatkan kartu pinjaman dan kartu angsuran pinjamannya.

5) Berdasarkan dokumen yang masuk kebagian pembukuan kabag membuat tanda terima bahwa nasabah telah menyerahkan agunan dan juga membuat bukti pengeluaran umum dan kemudian diserahkan kepada teller untuk dicairkan.

6) Semua dokumen diserahkan kembali sebagai arsip dan uang diserahkan pada nasabahserta bukti penerimaan pinjaman. 


\section{Pembahasan}

\section{Proses Pemberian Kredit}

Dalam proses pemberian kredit pada PT.BPR Lengayang terdapat beberapa tahap yaitu sebagai berikut:

a. Tahap mengajukan permohonan kredit

Pada tahap ini nasabah kredit harus mengisi formulir permohonan kredit serta memenuhi syarat-syarat yang sudahdisepakati oleh pihak bank dan diserahkan kepada pihak pelayanan kredit. dimana persyaratan yang harus dilengkapi sebagai berikut:

1) Fotocopy ktp suami istri

2) Fotocopy KK

3) Fotocopy jaminan

4) Pas foto $3 \times 4$

5) Surat keterangan usaha

Pengecekan kredit dilakukan oleh kabid kredit apakah kredit diterima atau ditolak. Jika ditolak maka ada masalah yang terjadi yaitu:

1) Usaha tidak terlihat

2) Jaminan tidak mencukupi dengan nominal plafon yang diminta.

Jika kredit diterima syaratnya sesuai yang dianjurkan oleh bank yaitu:

1) Usahanya terlihat

2) Tidak ada pinjaman yang macet ditempat lain

3) Jaminan sesuai dengan nominal yang diajukan.

b. Analisa Kredit

PT.BPR Lengayang menjalankan prinsip 5c dalam pemberian kredit sebagai berikut:

1) Character (Karakteristik)

Untuk memahami karakter nasabah, bank melakukan Wawancara secara langsung kepada calon nasabah, untuk mengetahui semua informasi, keinginan dan kepentingannasabah sebenarnya.

2) Capacity (Kemampuan)

Untuk melihat kemampuan nasabah bank melakukan pengecekan Checking BI apakah nasabah tersebut mempunyai hutang di bank lain maupun tidak.

3) Capital (Modal)

Penilaian terhadap permodalan nasabah PT. BPR Lengayang melihat keadaan dan situasi usaha nasabah untuk beberapa tahun yang lalu atau yang akan datang.

4) Collateral (Jaminan)

PT. BPR Lengayang memerlukan agunan untuk berjaga-jaga kemungkinan terjadinya penyimpangan yang dilakukan nasabah.

5) Condition of economy (Kondisi perekonomian)

Untuk mengetahui ekonomi nasabah PT.BPR Lengayang melaksanakan survei untuk meninjau usaha nasabah apakah usaha tersebut lancar atau tidak. 
c. Tahap persetujuan kredit

Dokumen yang telah disetujui oleh kabid kredit diserahkan kepada direktur untuk diputuskan apakah disetujui atau ditolak. Jika disetujui maka disiapkan administrasi kredit tersebut yaitu:

1) Besar jumlah kredit yang disetujui

2) Jangka waktu kredit

3) Biaya-biaya yang perlu dibayar oleh nasabah.

4) Mempersiapkan pengikatan kredit atau perjanjian.

d. Penandatanganan akad kredit/ perjanjian

Ketika kredit telah diterima, maka kedua bela pihak melaksanakan kesepakatan kredit dengan menandatangani akad kredit, dan pihak bank akan mengikat agunan yang dijaminkan.

e. Tahap pencairan

Pencairan uang nasabah dipindahkan ke rekening tabungan nasabah, kemudian dipotong biaya provisi, notaris, asuransi jiwa, dan administrasi. Setelah itu baru dilakukan penarikan oleh nasabah tersebut.

f. Pengawasan usaha nasabah

Bank melakukan pengawasan usaha nasabah untuk mengetahui informasi tentang usaha nasabah agar tidak terjadinya tunggakan kredit oleh nasabah itu sendiri.

g. Pengembalian Kredit

Memenuhi kewajibannya dalam mengembalikan jumlah pinjaman yang diterima dari pihak kreditur sesuai dengan jangka waktu yang telah ditentukan. Dalam pengembalian kredit semua kewajiban pengembalian kredit harus selesaikan sesuai dengan waktu pelunasan. pelunasan meliputi utang pokok, utang bunga, denda-denda jika adadan biaya-biaya administrasi lainnya.

Berikut hal-hal yang diperhatikan oleh PT.BPR lengayang dalam pengembalian kredit sebagai berikut:

1) Perhitungan jumlah hutangpeminjam yang harus diselesaikan sampai tanggal pelunasan yakni:

a) Hutang pokok

b) Hutang bunga

c) Denda

d) Biaya administrasi

2) Dilunasi rekening atas nama nasabah peminjam ditutup.

3) Penyerahan kembali dokumen-dokumen jaminan kepada nasabah hanya dapat setelah menyelesaikan semua tanda terima dan ditandatangani yang bersangkutan.

4) Pengembalian dokumen-dokumen jaminan hanya dapat dilakukan sepengetahuan dan seizin direksi. 


\section{Perkembangan Pemberian Kredit Dan Penerima Kredit \\ Perkembangan Pemberian Kredit}

Pemberian kredit oleh PT.BPR Lengayang pada saat ini sudah berkembang, karena telah memiliki berbagai cara memberikan jasa perbankannya ke masyarakat. Perkembangan pemberian kredit tersebut dapat dilihat dari grafik sebagai berikut:

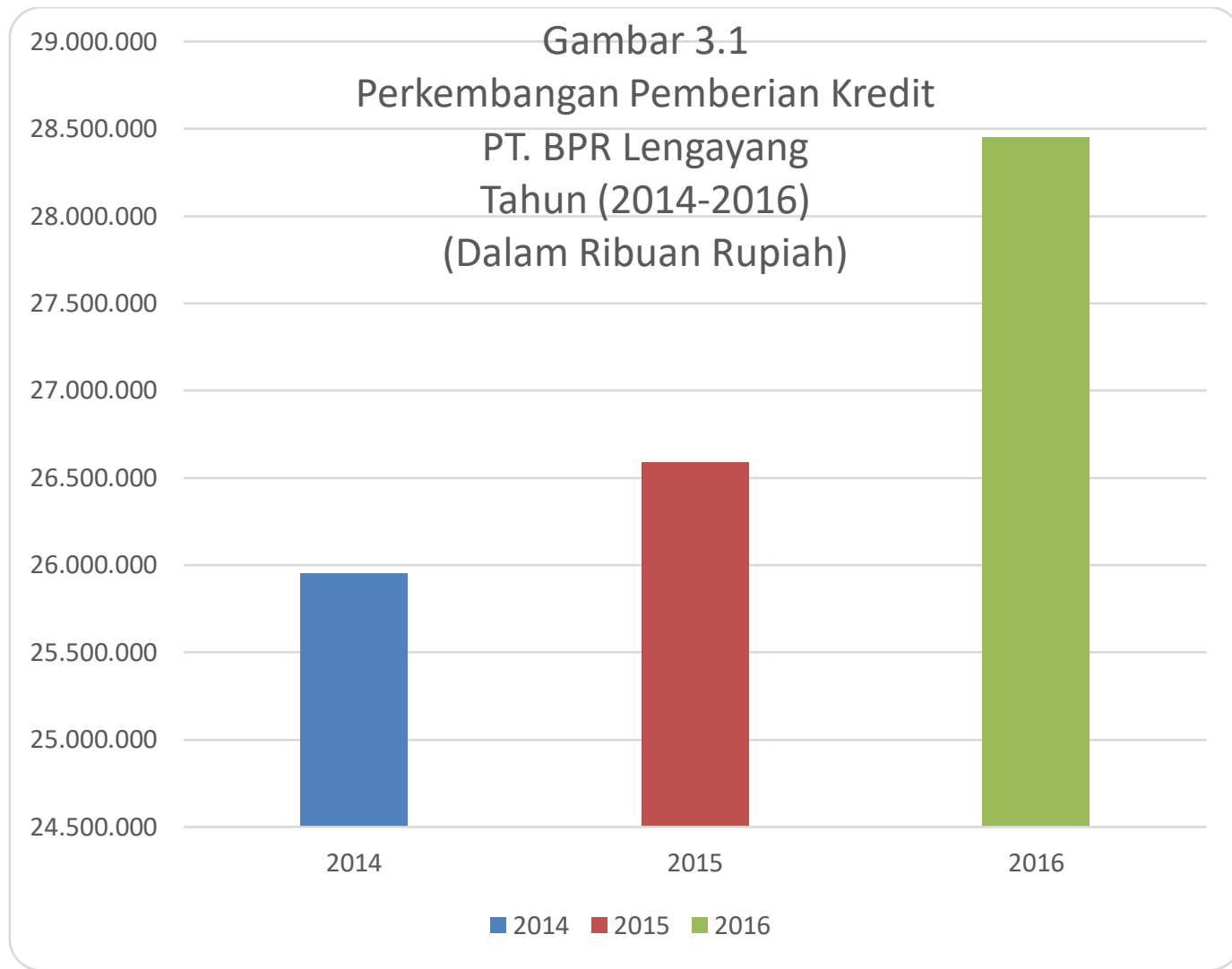

Sumber: PT.BPR Lengayang

Dari data diatas,dapat diketahui bahwa jumlah pemberian kredit mengalami peningkatan setiap tahunnya. Pada tahun 2014 jumlah perkembangan kredit yang diberikan senilai Rp. 25.955.263 dan dilihat pada tahun 2015 kredit yang diberikan senilai Rp.26.587.911.Pada tahun berikutnya yaitu 2016 terjadi kenaikan yang cukup signifikan menjadi Rp. 28.451.020.

Peningkatan pemberian kredit kepada nasabah terjadi karena meningkatnya jumlah tabungan dan deposito sehingga dana yang bisa disalurkan untuk kredit pun meningkat. Jadi pemberian kredit bisa berkembang kalau nasabah yang akan diberikan pinjaman memenuhi persyaratan dan dana pun tersedia.

\section{Perkembangan Penerima Kredit}

Dilihat dari jumlah penerimaan kredit pada PT.BPR Lengayang dapat dilihat pada tabel berikut: 
Tabel

Perkembangan Penerima Kredit

PT.BPR Lengayang

Tahun (2014-2016)

\begin{tabular}{llllllllllll}
\hline T & a & h & & u & n & Jumlah Peminjam & N a i k / T u r u n \\
\hline 2 & 0 & 1 & 4 & 7 & 8 & 5 & - & & & \\
2 & 0 & 1 & 5 & 8 & 8 & 4 & $\mathrm{~N}$ & $\mathrm{a}$ & $\mathrm{i}$ & $\mathrm{k}$ \\
2 & 0 & 1 & 6 & 9 & 8 & 1 & $\mathrm{~N}$ & $\mathrm{a}$ & $\mathrm{i}$ & $\mathrm{k}$
\end{tabular}

Sumber: PT.BPR Lengayang

Dari data di atas dapat diketahui bahwa penerimaan kredit pada PT.BPR Lengayang mengalami kenaikan. Pada tahun 2014 berjumlah 785 orang.Pada tahun 2015 penerimaan kredit mengalami peningkatan 884 orang dan tahun 2016 penerimaan kredit mengalami kenaikan lagi yaitu 981 orang.

Setiap tahun jumlah nasabah meningkat dikarenakan nasabah yang mengajukan pinjaman ke PT. BPR Lengayang tidak ada macet di tempat lain, Usaha yang dibantu oleh PT.BPR Lengayang pun terlihat dan jaminan sesuai dengan nominal kredit yang diminta oleh nasabah.

\section{KESIMPULAN}

Proses pemberian kredit yang dilakukan pada PT.BPR Lengayang dimulai dari tahap pengajuan permohonan, analisa kredit, keputusan kredit, penandatanganan akad kredit, pencairan, pengawasan usaha nasabah, pengembalian kredit. Perkembangan pemberian kredit dan perkembangan penerima kredit meningkat setiap tahun karena pihak bank memberikan kepercayaannya kepada debitur sebab tidak ada kredit macet di tempat lain.

\section{UCAPAN TERIMAKSIH}

Penulis ucapkan puji dan syukur atas kehadiran Allah SWT, yang telah melimpahkan rahmat dan hidayahnya kepada penulis. Penulis ingin mengucapkan terima kasih kepada PT. BPR Lengayang yang telah memberikan motivasi, masukan-masukan yang bermanfaat bagi penulis dan terima kasih untuk teman-teman atas semangat dan dukungannya dalam pembuatan Artikel ini. Akhir kata penulis ucapkan terima kasih. Semoga apa yang penulis tuangkan dalam Artikel ini memberikan manfaat terutama bagi saya sendiri selaku penulis. Aamiin ya Robba'alamin.

\section{DAFTAR PUSTAKA}

Alanshari, F., \& Marlius, D. (2018). Prosedur Pemberian Kredit KPR Pada PT. Bank Tabungan Negara (Persero) Tbk Cabang Pembantu Bukittinggi. 2014, 1-11. https://doi.org/10.31227/osf.io/rsfhc

Amelia, L., \& Marlius, D. (2018). Pengendalian Kredit Dalam Upaya Menciptakan Bank Yang Sehat Pada PT. Bank Pembangunan Daerah Sumatera Barat Cabang Utama Padang. 2007, 1-11. https://doi.org/10.31227/osf.io/kpc64 
Andriani, B., \& Susanto, R. (2019). Pengawasan Kredit PT. Bank Perkreditan Rakyat (BPR) Ophir Pasaman Barat. 1-12. https://doi.org/10.31219/osf.io/aunvc

Anggraini, D., \& Nasution, S. H. (2013). Peranan Kredit Usaha Rakyat (Kur) Bagi Pengembangan UMKM Di Kota Medan (Studi Kasus Bank BRI). Jurnal Ekonomi Dan Keuangan, 1(3), 14879.

Asyari, A., \& Marlius, D. (2021). Proses Penyelesaian Kredit Bermasalah Pada PT. BPD Sumatera Barat Cabang Pasar Raya Padang. https://doi.org/10.31219/osf.io/3hfcr

Gustiyan, H. (2014). Analisis Faktor-Faktor Yang Mempengaruhi Kinerja Sistem Informasi Akuntansi Pada Bank Perkreditan Rakyat (BPR) Di Tanjungpinang. 090462201140, 1-21.

Handayani, M., \& Marlius, D. (2017). Analisis Tingkat Kesehatan PT. BPR Batang Kapas. https://doi.org/10.31227/osf.io/bq48z

Jadmiko, A. M. (n.d.). Analisis Perbandingan Resiko Keuangan Bank Perkreditan Rakyat(BPR) Perseroan Terbatas Dan BPR Koperasi.

Kasmir, D. (2013). Bank Dan Lembaga Keuangan Lainnya.

Widayati, R., \& Efriani, M. (2019). Aktivitas Pemberian Kredit Usaha Pada PT. Bank Perkreditan Rakyat Batang Kapas. 1-10. https://doi.org/10.31219/osf.io/xh8sw

Achmad Chosyali*, T. S. (2019). Optimalisasi Peningkatan Kualitas Kredit Dalam Rangka Mengatasi Kredit Bermasalah. Law Reform, 15(1), 98. https://doi.org/10.14710/lr.v15i1.23357

Shanjaya, A. R., \& Marlius, D. (2018). Peranan Laporan Keuangan Dalam Kebijaksanaan Pemberian Kredit Kepada Calon Nasabah Pada Pt. Bpr Batang Kapas. 1-12. https://doi.org/10.31227/osf.io/uxmg6

Tumbel2, C. Y. (2015). Aspek-Aspek Penilaian Dalam Pemberian Kredit Bank. Lex Privatum, 3(3), 44-51.

Widayati, R., \& Putri, D. E. (2019). Pelaksanaan Kredit Pada Bank Perkreditan Rakyat Lpn Pasar Baru Durian Sawahlunto. 1-13. https://doi.org/10.31219/osf.io/jw2za

Wilardjo, S. B. (2014). Pengertian, Peranan, dan Perkembangan Bank Syariah di Indonesia. Igarss 2014, 2(1), 1-5.

Yuliana, E. W., \& Widianti, H. (2014). Sistem Pemberian Kredit Pada Unit Simpan Pinjam Kud Karya Mina Kota Tegal. Politeknik Harapan Bersama, 09, 1-8. 